\title{
Evaluating the importance of Marine Protected Areas for the conservation of hawksbill turtles Eretmochelys imbricata nesting in the Dominican Republic
}

\author{
Ohiana Revuelta ${ }^{1, *}$, Lucy Hawkes ${ }^{2}$, Yolanda M. León ${ }^{3,4}$, Brendan J. Godley², \\ Juan A. Raga ${ }^{1}$, Jesús Tomás ${ }^{1}$ \\ ${ }^{1}$ Cavanilles Institute of Biodiversity and Evolutionary Biology, University of Valencia, PO Box 22085, 46071 Valencia, Spain \\ ${ }^{2}$ University of Exeter, Centre for Ecology and Conservation, College of Life and Environmental Sciences, Penryn TR10 9EZ, UK \\ ${ }^{3}$ Instituto Tecnológico de Santo Domingo, Urb. Galá, Santo Domingo 10602, Dominican Republic \\ ${ }^{4}$ Grupo Jaragua, El Vergel, Santo Domingo 10107, Dominican Republic
}

\begin{abstract}
Understanding spatial and temporal habitat-use patterns to protect both foraging and breeding grounds of species of concern is crucial for successful conservation. Saona Island in Del Este National Park (DENP), south-eastern Dominican Republic (DR), hosts the only major hawksbill (Eretmochelys imbricata) nesting area in the DR $\left(100\right.$ nests $\mathrm{yr}^{-1}, \mathrm{SD}=8.4$, range $=$ 93-111), with the population having been critically reduced through hunting. We satellite tracked 9 female hawksbill turtles, and present analyses of their core-use areas with respect to Marine Protected Areas (MPAs) in both their internesting and foraging areas. Kernel utilization distributions indicated that during the internesting period all turtles remained close to their nesting beaches in small home ranges in the territorial waters of the DR, mostly over the continental shelf $(<200 \mathrm{~m}$ depth). Common core-use areas were located inside the DENP, and $82.7 \%$ of all locations were within the DENP. In foraging areas, only $23 \%$ of locations were inside MPAs, either in waters of the DR or in waters of the Bahamas, Nicaragua and Honduras. Our results highlight that the protected areas of the DR are vital for hawksbill conservation, and the enforcement of existing legislation governing protected areas in the country is crucial. The present study also corroborates that the waters off Nicaragua and Honduras are exceptionally important foraging areas for hawksbills in the Caribbean, showing the turtle's vulnerability in these waters.
\end{abstract}

KEY WORDS: Core use areas · Hawksbill turtle $\cdot$ Internesting behaviour $\cdot$ Marine Protected Areas $\cdot$ Satellite tracking

\section{INTRODUCTION}

Many marine vertebrate species are of conservation concern as the result of a range of past and ongoing threats (Read et al. 2006, Hoffmann et al. 2011), and the establishment of marine protected areas (MPAs) has been promoted as a key management measure for their conservation (Agardy 1994, Edgar et al. 2014). The management and conserva-

\footnotetext{
*Corresponding author: ohiana.revuelta@uv.es
}

tion effectiveness of MPAs requires full knowledge of the life-history stages of the species they are intended to preserve (Edgar 2011, Scott et al. 2012, Edgar et al. 2014, Mazaris et al. 2014). For highly migratory marine species this means knowledge about their migration routes, as well as the use of their foraging and breeding grounds (Shaffer et al. 2006, Shillinger et al. 2008). Thanks to a revolution in the use of location technologies for tracking the at-

(C) The authors 2015. Open Access under Creative Commons by Attribution Licence. Use, distribution and reproduction are unrestricted. Authors and original publication must be credited. 
sea movements of a range of marine species ('biologging'; Hooker et al. 2007, Rutz \& Hays 2009, Bograd et al. 2010), we now know a great deal about the movements and behaviour of many marine species and arguably the most about marine turtles (Godley et al. 2008, Hawkes et al. 2011, Maxwell et al. 2011, Pendoley et al. 2014).

The hawksbill turtle Eretmochelys imbricata is a marine turtle distributed in tropical and subtropical areas of the Atlantic, Pacific and Indian Oceans and, currently, is listed globally as 'Critically Endangered' by the International Union for Conservation of Nature and Natural Resources (IUCN 2013). In the Caribbean, this species is thought to be a major predator in coral reef ecosystems, with sponges constituting the main component of its diet (Meylan 1988, León \& Diez 1999). Numerous studies have suggested the key role of this species in maintaining the structure, ecology and evolution of coral reefs (León \& Bjorndal 2002, Bjorndal \& Jackson 2003). During the nesting season, which usually spans several months, females return repeatedly to the same beach to lay a variable number of clutches (Allen et al. 2010, Marcovaldi et al. 2012, Walcott et al. 2012, Phillips et al. 2013), similar to that documented for other marine turtle species. However, some populations of marine turtles remain within $100 \mathrm{~m}$ of the nesting beaches between nesting attempts (green turtles Chelonia mydas on Ascension Island; Hays et al. 1999), while others may travel up to $100 \mathrm{~km}$ from the nesting beach to alternative sites (loggerhead turtles Caretta caretta in Greece; Schofield et al. 2010). After breeding, and in a similar manner to other marine turtle species (loggerhead turtles: Hawkes et al. 2011, Schofield et al. 2013a; flatback turtles Natator depressus: Pendoley et al. 2014), adult hawksbill turtles are then thought to migrate away from the nesting beach to foraging grounds (Meylan et al. 2011). Migratory movements of adult marine turtles, tracked using satellite telemetry, show a broad range of post-nesting migratory strategies, even within studies. These include turtles remaining in waters proximate to the nesting beaches and others migrating to foreign waters many hundreds to thousands of kilometres away (loggerheads: Hawkes et al. 2011, Schofield et al. 2013a; green turtles: Seminoff et al. 2008; hawksbills: van Dam et al. 2008, Horrocks et al. 2011, Hawkes et al. 2012, Moncada et al. 2012).

The Dominican Republic (DR) in the eastern Caribbean hosts regionally significant numbers of nesting hawksbill turtles (Revuelta et al. 2012), but current nesting is largely restricted to protected areas. Saona Island in Del Este National Park
(DENP), south-eastern DR, hosts the last major nesting area in the country $\left(\sim 100\right.$ nests $\mathrm{yr}^{-1}$; Revuelta et al. 2012). Although nesting beaches are in a protected area, there has been a marked reduction in the abundance of this species, and egg take is still a major threat at these beaches (Revuelta et al. 2012, 2013).

Here we analyse tracking data from DR nesting hawksbills (building on findings in Hawkes et al. 2012) with respect to (1) behaviour of hawksbill females during the period from the date of attachment at nesting until the final nesting event before departure from the breeding grounds and (2) an assessment of the level of protection afforded to these turtles in their breeding and foraging areas.

\section{MATERIALS AND METHODS}

\section{Tagging area}

Surveys of nesting hawksbill turtles were carried out in the Jaragua National Park (JNP, south-west DR, 17.816' N, 71.533' W; Fig. 1) and Del Este National Park (DENP, south-eastern DR, 18.807' N, $68.844^{\prime} \mathrm{W}$; Fig. 1). Both parks were added to the UNESCO World Heritage list in 2001. JNP covers $1374 \mathrm{~km}^{2}$, of which $905 \mathrm{~km}^{2}$ comprises coastal and marine areas. Hawksbill turtles nest at the westernmost beaches of the park, Bahía de las Águilas (4.4 km long) and La Cueva $(2.5 \mathrm{~km})$. The park receives ca. 20000 visitors $\mathrm{yr}^{-1}$ (Wielgus et al. 2010). DENP is the second largest coastal national park in the DR, and comprises some of the south-eastern DR and Saona Island (which has an area of ca. $110 \mathrm{~km}^{2}$ ). The level of protection does not vary across the park. Hawksbill nesting activity is concentrated on 12 sandy beaches (altogether comprising a total of $15 \mathrm{~km}$ ) interspersed with rocky areas (Revuelta et al. 2013). The adjacent neritic zone is characterized by a wide continental shelf comprising fringing reefs and rocky bottom communities mixed with seagrass beds. Despite the DENP's designation as a national park, the government of the DR allows small-scale artisanal fisheries to exist within its boundaries, mainly for local consumption. However, overfishing has affected the area, with populations of invertebrates (conch and spiny lobster) and reef fish becoming highly depleted (Chiappone et al. 2000). In addition, Saona Island is one of the most popular tourist destinations in the $\mathrm{DR}$, with up to 1000 visitors a day (Macleod 2001), resulting in heavy motor boat traffic, especially off the west of the island. 

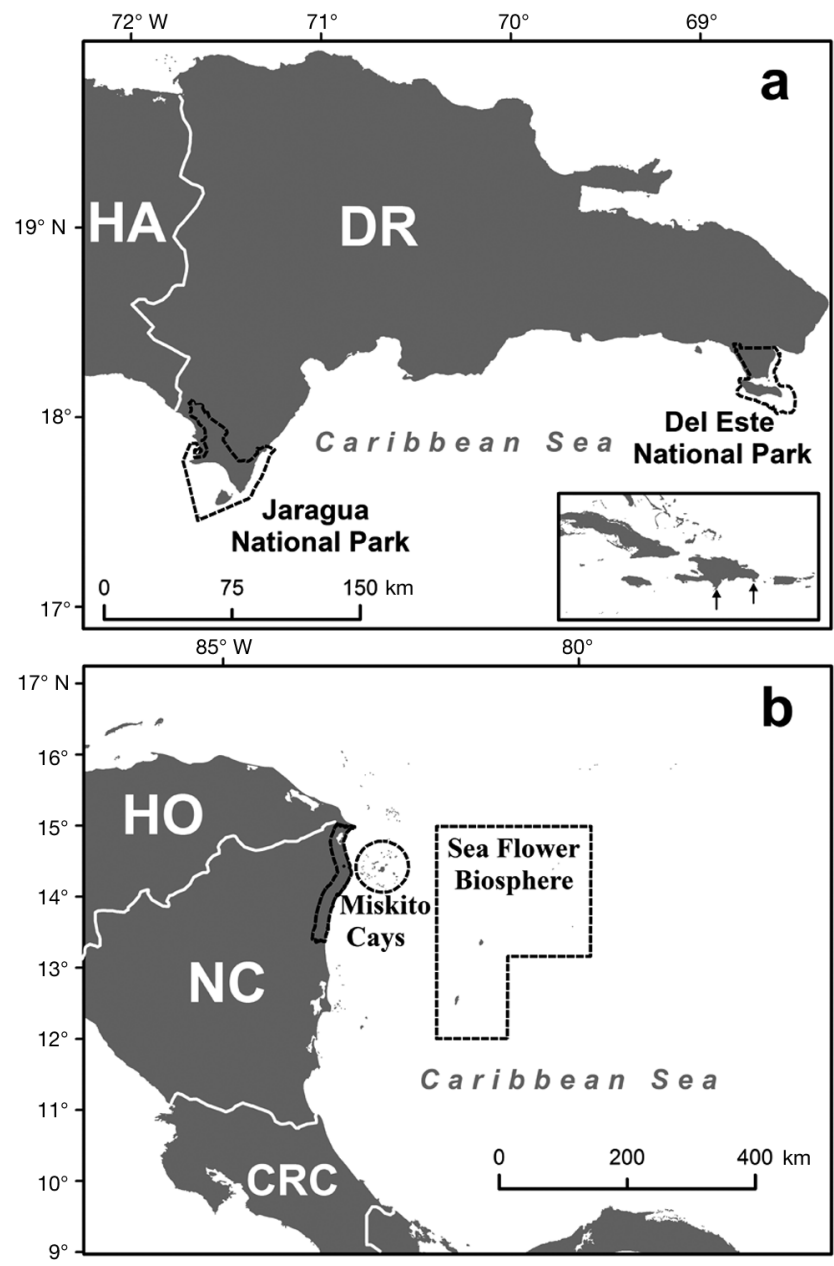

Fig. 1. Study area. (a) Map of the Dominican Republic (DR) indicating hawksbill (Eretmochelys imbricata) nesting and foraging areas in protected areas of Jaragua National Park (JNP; south-west DR) and Del Este National Park (DENP; south-east DR, including Saona Island) where turtles were tagged. (b) Hawksbill foraging areas in the western Caribbean. Boundary lines for marine protected areas in the Caribbean Sea are shown. HA: Haiti; HO: Honduras; NC: Nicaragua; CRC: Costa Rica

\section{Marine turtle tracking and satellite data filtering}

We attached satellite transmitters to a total of 9 nesting hawksbill turtles, 8 on Saona Island in August-September 2008 and September-December 2009; and 1 (Ei8) in JNP in September 2009. Turtles ranged in size from 81.0 to $94.0 \mathrm{~cm}$ curved carapace length $\left(\mathrm{CCL}_{\text {; }}\right.$ mean $\pm \mathrm{SD}: 87.3 \pm 4.4 \mathrm{~cm}$; Table 1$)$. None of these turtles had previous transmitters of any type. Transmitters were Wildlife Computers SPOT5 tags $(\mathrm{n}=5)$ and Sirtrack Kiwisat 101 tags $(\mathrm{n}=4)$ and were set to transmit whenever they were at the sea surface, i.e. a duty cycle of $100 \%$ on. To attach the units, we detained each turtle inside a portable wooden 'corral' following nesting or nesting attempts, intercepting them on their way back to the sea. The carapace of each turtle was prepared by scrubbing to remove epibionts and sand and cleaning with acetone. The units were attached to the second vertebral scute of the carapace with 2part epoxy and covered with a layer of anti-fouling paint (Blumenthal et al. 2006). Before attaching the transmitter, each turtle was measured (CCL) and tagged with small metal Inconel tags to the front flippers. Once tagging was complete we removed the corral, allowing the turtle to return to the sea.

For all transmitters, data were downloaded from the ARGOS satellite system and subsequently analysed with the satellite tracking and analysis tool (STAT; Coyne \& Godley 2005) to archive and filter location data. For each reported location, ARGOS calculates a measure of accuracy using 6 'location classes' (LC): 3, 2, 1, 0, A and B. ARGOS assigns accuracy estimates of $<250 \mathrm{~m}$ for LC3, 250 to $<500 \mathrm{~m}$ for LC2, 500 to $<1500 \mathrm{~m}$ for LC1 and $>1500 \mathrm{~m}$ for LC0 (CLS 2011). As in previous hawksbill telemetry studies (Cuevas et al. 2008, Gaos et al. 2012), the majority of our LCs were categorized as B (ARGOS does not provide estimated errors for $\mathrm{LC} \mathrm{A}$ or $\mathrm{B}$ ); thus, we considered the positions LC3, LC2, LC1, LCA and LCB to avoid loss of relevant location data (Hays et al. 2001). These LCs were retained and filtered to remove biologically unrealistic speeds ( $>5 \mathrm{~km} \mathrm{~h}^{-1}$; see Luschi et al. 1998), turning angles $\left(<25^{\circ}\right.$ were removed) and elevations ( $>0 \mathrm{~m}$ above sea level).

\section{Identifying nesting events}

Due to survey limitations (i.e. it was not possible to survey the entire beach area every night), we could not allocate nests to particular females. Similar to methodology used by Rees et al. (2010), Tucker (2010) and Maxwell et al. (2011), in the present study nesting activity was extracted from the tracking data by evaluating the following criteria, classing a nesting event as having occurred when all of the following 4 criteria were fulfilled: (1) locations were within $1 \mathrm{~km}$ of the coastline; (2) the turtle made directed onshore movement; (3) movements occurred approximately 2 wk after the last known nesting event (for hawksbill turtles, the 'internesting period' [Miller 1997]; the time between 2 subsequent nesting events is thought to be approximately $15 \mathrm{~d}$ [Beggs et al. 2007]); and (4) high ARGOS LCs (3, 2 and 1) occurred within a short time span. 
Table 1. Summary information of Saona nesting hawksbill (Eretmochelys imbricata) behaviour and habitat utilisation during the nesting season. CCL: curved carapace length; IN: internesting; IN tracking duration: defined as time from tagging date until the last internesting location; inferred nesting dates: nesting emergences inferred from satellite-tracking data during the nesting season; IN period: number of days between 2 consecutive nesting events. Turtles Ei3 and Ei9 stopped sending signals during their second nesting season in 2011; thus, we could not estimate time in the IN after the last nest. Turtles Ei4 and Ei8 immediately left coastal waters; therefore, no IN period or clutch frequency could be estimated for these turtles. (-): No data; 0: turtle left Saona the day the transmitter was fitted

\begin{tabular}{|c|c|c|c|c|c|c|c|c|c|}
\hline Turtle & $\begin{array}{l}\text { Transmitter } \\
\text { attachment } \\
(\mathrm{dd} / \mathrm{mm} / \mathrm{yy})\end{array}$ & $\begin{array}{l}\text { CCL } \\
(\mathrm{cm})\end{array}$ & $\begin{array}{l}\text { IN tracking } \\
\text { duration } \\
\text { (d) }\end{array}$ & $\begin{array}{c}\text { Inferred } \\
\text { nesting } \\
\text { (dd/mm/yy) }\end{array}$ & $\begin{array}{c}\mathrm{IN} \\
\text { period }(\mathrm{d}) \\
(\text { mean } \pm \mathrm{SD})\end{array}$ & $\begin{array}{l}\text { Clutch } \\
\text { freq. }\end{array}$ & $\begin{array}{l}\text { Days in } \\
\text { IN after } \\
\text { last nest }\end{array}$ & $\begin{array}{l}\text { Swim speed } \\
\left(\mathrm{km} \mathrm{h}^{-1}\right) \\
(\text { mean } \pm \mathrm{SD})\end{array}$ & $\begin{array}{l}\text { Max. dist. } \\
\text { offshore } \\
(\mathrm{km})\end{array}$ \\
\hline Ei1 & 11/08/2008 & 84 & 34 & $\begin{array}{l}15 / 08 / 2008 \\
30 / 08 / 2008 \\
14 / 09 / 2008\end{array}$ & $15.0 \pm 0.0$ & 3 & 1 & $1.4 \pm 1.2$ & 17 \\
\hline $\mathrm{Ei}^{\mathrm{a}}$ & 28/08/2008 & 90 & 60 & $\begin{array}{l}16 / 09 / 2008 \\
29 / 09 / 2008 \\
14 / 10 / 2008\end{array}$ & $14.0 \pm 1.4$ & 3 & 14 & $1.5 \pm 1.3$ & 28 \\
\hline Ei2 & - & - & - & - & - & - & - & - & 33 \\
\hline $\mathrm{Ei}^{\mathrm{a}}$ & 29/08/2008 & 90 & 48 & $\begin{array}{l}15 / 09 / 2008 \\
30 / 09 / 2008 \\
14 / 10 / 2008\end{array}$ & $15.3 \pm 1.4$ & 3 & 1 & $1.2 \pm 1.3$ & 25 \\
\hline Ei3 & - & - & 52 & $\begin{array}{l}24 / 07 / 2011 \\
10 / 08 / 2011\end{array}$ & 17.0 & 2 & - & $0.7 \pm 0.8$ & 13 \\
\hline Ei4 & 19/09/2008 & 94 & 0 & - & - & - & 0 & - & - \\
\hline Ei5 & $30 / 09 / 2008$ & 92 & 28 & 15/10/2008 & 15.0 & 2 & 13 & $2.4 \pm 2.7$ & 39 \\
\hline Ei6 & 27/10/2008 & 81 & 51 & $\begin{array}{l}28 / 11 / 2008 \\
14 / 12 / 2008\end{array}$ & 16.0 & 3 & 2 & $1.4 \pm 1.6$ & 17 \\
\hline Ei7 & 01/11/2008 & 84 & 37 & $\begin{array}{l}18 / 11 / 2008 \\
03 / 12 / 2008\end{array}$ & $16.0 \pm 1.4$ & 3 & 4 & $1.4 \pm 1.5$ & 16 \\
\hline Ei8 & 07/08/2009 & 84 & 0 & - & - & - & 0 & - & - \\
\hline Ei9 & 01/09/2009 & 87 & 64 & $\begin{array}{l}02 / 07 / 2011 \\
18 / 07 / 2011 \\
02 / 08 / 2011 \\
18 / 08 / 2011\end{array}$ & $15.7 \pm 0.6$ & 4 & - & $0.8 \pm 1.0$ & 14 \\
\hline
\end{tabular}

\section{Turtles' core-use areas and distribution within MPAs}

To minimize autocorrelation in spatial analysis we generated median daily locations for each turtle from the filtered locations (James et al. 2005). To determine core-use areas, foraging and nesting data were extracted using displacement plots (a plot showing the distance, i.e. displacement, from the release site for each location received from each turtle, over time; see Blumenthal et al. 2006, Hawkes et al. 2012), which allowed them to be differentiated from areas of migratory-use. Home range size was then estimated separately for foraging and nesting periods using minimum convex polygons (MCP), a non-statistical measure which encapsulates the area used by an individual within a polygon formed by joining the outermost sighting positions (Burt 1943). MCP is a simple calculation that allows for comparisons between studies (Hooge et al. 1999), but is unable to describe fine-scale movements and preferred area used within the polygon. It may also be inflated by inaccurate yet plausible data outside the true area of utilisation (Laver \& Kelly 2008). Therefore, core-use areas were identified using fixed kernel density estimation (KDE), with individual kernel contours delineated using a smoothing factor (h) of 1.5 for internesting area (area occupied during nesting season) and 2.5 for foraging grounds (areas where turtles migrate and settle to feed during nonnesting periods). Density distributions were represented on the maps by the 50 and $90 \%$ utilisation distribution (UD) contours. We used a $90 \% \mathrm{KDE}$ to estimate the overall home foraging and internesting home range of a turtle, and a $50 \% \mathrm{KDE}$ to represent the core area of activity (Powell 2000). For turtles tracked through 2 consecutive nesting seasons, KDE was calculated separately for each nesting season. Following the methodology of Hart et al. (2013) we did not estimate KDEs for turtles that transmitted for $<20 \mathrm{~d}$ (i.e. had fewer than 20 median daily locations). 


\section{Common use areas}

Common core-use areas, where multiple turtles spent time during breeding periods, were generated for all turtles combined. These areas were determined by pooling the data of all locations to obtain an overall core area use for all turtles; afterwards we calculated 90 and $50 \%$ KDEs.

To analyse the location of turtles with respect to MPAs, median daily turtle location data were overlaid on the World Database on Protected Areas (www.wdpa.org). Site fidelity was quantified using a residency index (Mason \& Lowe 2010), calculated by dividing the number of days a female was detected within the boundaries of an MPA by the number of days the female was monitored (i.e. nesting season and foraging period). Values ranged from 0 , indicating no residency, to 1 indicating a high degree of residency. All spatial analyses were carried out in ArcGIS 10 (ESRI 2010). Data are presented as mean values $( \pm \mathrm{SD})$ unless otherwise stated.

\section{RESULTS}

Overall transmission success rate (median number of locations received per day per turtle) ranged between 1.8 and 5.6 locations $\mathrm{d}^{-1}$ during the nesting season and 1.0 and 4.2 locations $\mathrm{d}^{-1}$ in foraging grounds (Table 2). Transmitter duration was variable: Turtle Ei1 was only tracked during the nesting season; Turtles Ei4 and Ei8 departed immediately following device attachment and were therefore only tracked during the foraging period; the 6 other turtles (Ei2, Ei3, Ei5, Ei6, Ei7 and Ei9) were tracked during both internesting and foraging (Table 2). Transmitters attached to 3 turtles (Ei2, Ei3 and Ei9) functioned for particularly long periods, permitting insight into multi-year space use. These 3 turtles were tracked from arrival at their foraging grounds until their departure to breed and nest again in the DR.

\section{Insight into the nesting season behaviour}

We analysed a total of 370 tracking days from the 7 turtles for which we had internesting data (see above). Individual tracking durations during the nesting season ranged from 0 to $64 \mathrm{~d}(37.4 \pm 22.7 \mathrm{~d}$; Table 1). Excluding Turtles Ei4 and Ei8, as well as Turtle Ei9's first nesting season (as it left coastal waters immediately after laying the last clutch), we estimated that hawksbill females migrate from the nesting area $4.3 \pm 5.8 \mathrm{~d}$ after laying their last clutch of the season (range: 0-14 d; Table 1). Twenty nesting events were inferred from 7 turtles (including 2 turtles that were recorded nesting in 2 different years; Table 1). We estimated time between nesting events ('internesting period'; Miller 1997) of $15.5 \pm 0.9 \mathrm{~d}$ (range: 14-17 d). Turtles Ei1, Ei2 and Ei3 did not successfully nest at the time of transmitter deployment;

Table 2. Transmission success (mean number of locations received per day [mdl]), Minimum convex polygon (MCP) and kernel density estimation (KDE) for hawksbill turtles Eretmochelys imbricata in their internesting and foraging grounds. BH: Bahamas; CO: Colombia; DR: Dominican Republic; HO: Honduras; NC: Nicaragua. Turtle Ei1 stopped transmitting before arriving at the foraging ground. Turtle Ei2 $(\mathrm{a}, \mathrm{b})$ was tracked during 2 nesting and foraging seasons. Ei3 was tracked during 2 nesting seasons $(\mathrm{a}, \mathrm{b})$ and 1 foraging season (a). Turtles Ei4 and Ei8 departed immediately following device attachment. Turtle Ei5 had fewer than 20 median daily locations $(n=16)$ during the nesting season for KDE analysis. MCP sizes in foraging grounds also reported in Hawkes et al. (2012). (-): No data available

\begin{tabular}{|c|c|c|c|c|c|c|c|c|c|}
\hline \multirow[t]{2}{*}{ Turtle } & \multirow{2}{*}{ mdl } & \multicolumn{2}{|c|}{ Internesting - } & \multirow[b]{2}{*}{$\begin{array}{c}50 \% \mathrm{KDE} \\
\left(\mathrm{km}^{2}\right)\end{array}$} & \multirow[b]{2}{*}{ mdl } & \multirow[b]{2}{*}{$\begin{array}{l}\mathrm{MCP} \\
\left(\mathrm{km}^{2}\right)\end{array}$} & \multirow{2}{*}{$\begin{array}{c}\text {-Foraging } \\
90 \% \mathrm{KDE} \\
\left(\mathrm{km}^{2}\right)\end{array}$} & \multirow[b]{2}{*}{$\begin{array}{c}50 \% \mathrm{KDE} \\
\left(\mathrm{km}^{2}\right)\end{array}$} & \multirow[b]{2}{*}{$\begin{array}{c}\text { Maritime } \\
\text { boundaries }\end{array}$} \\
\hline & & $\begin{array}{l}\mathrm{MCP} \\
\left(\mathrm{km}^{2}\right)\end{array}$ & $\begin{array}{c}90 \% \mathrm{KDE} \\
\left(\mathrm{km}^{2}\right)\end{array}$ & & & & & & \\
\hline Ei1 & $3.1 \pm 2.0$ & 306.4 & 26.9 & 11.1 & - & - & - & - & - \\
\hline Ei2a & $1.9 \pm 1.8$ & 302.3 & 28.3 & 8.7 & $2.2 \pm 1.4$ & 8124.1 & 279.1 & 21.4 & $\mathrm{NC} / \mathrm{HO}$ \\
\hline $\mathrm{Ei} 2 \mathrm{~b}$ & & 1101.2 & 39.0 & 16.5 & & 38.2 & 14.2 & 3.4 & $\mathrm{NC}$ \\
\hline Ei3a & $3.8 \pm 2.6$ & 290.7 & 31.9 & 9.3 & $2.5 \pm 1.5$ & 27001 & 59.4 & 12.7 & $\mathrm{NC} / \mathrm{CO}$ \\
\hline Ei3b & & 68.4 & 24.0 & 5.4 & - & - & - & - & - \\
\hline Ei4 & - & - & - & - & $1.8 \pm 1.2$ & 7033.2 & 230.1 & 38.4 & $\mathrm{NC} / \mathrm{HO}$ \\
\hline Ei5 & $2.1 \pm 1.8$ & 947.4 & - & - & $1.0 \pm 1.8$ & 1968.7 & 57.3 & 15.6 & DR \\
\hline Ei6 & $2.3 \pm 1.3$ & 219.8 & 24.1 & 13.3 & $2.0 \pm 1.4$ & 1772.2 & 29.9 & 6.9 & $\mathrm{DR}$ \\
\hline Ei7 & $1.8 \pm 1.3$ & 238.1 & 61.6 & 24.7 & $1.3 \pm 1.2$ & 3456.3 & 65.1 & 20.3 & $\mathrm{BH}$ \\
\hline Ei8 & - & - & - & - & $2.4 \pm 1.4$ & 416.7 & 13.1 & 3.4 & $\mathrm{HO}$ \\
\hline Ei9 & $5.6 \pm 2.7$ & 158.3 & 60.7 & 16.4 & $4.2 \pm 2.0$ & 13219 & 129.5 & 23.9 & $\mathrm{NC} / \mathrm{HO}$ \\
\hline
\end{tabular}


thus, internesting period was determined from the first inferred nesting date instead. Mean minimum clutch frequency of 7 females for which we have records was $2.9 \pm 0.6$ clutches (range: $2-4$ clutches; Table 1).
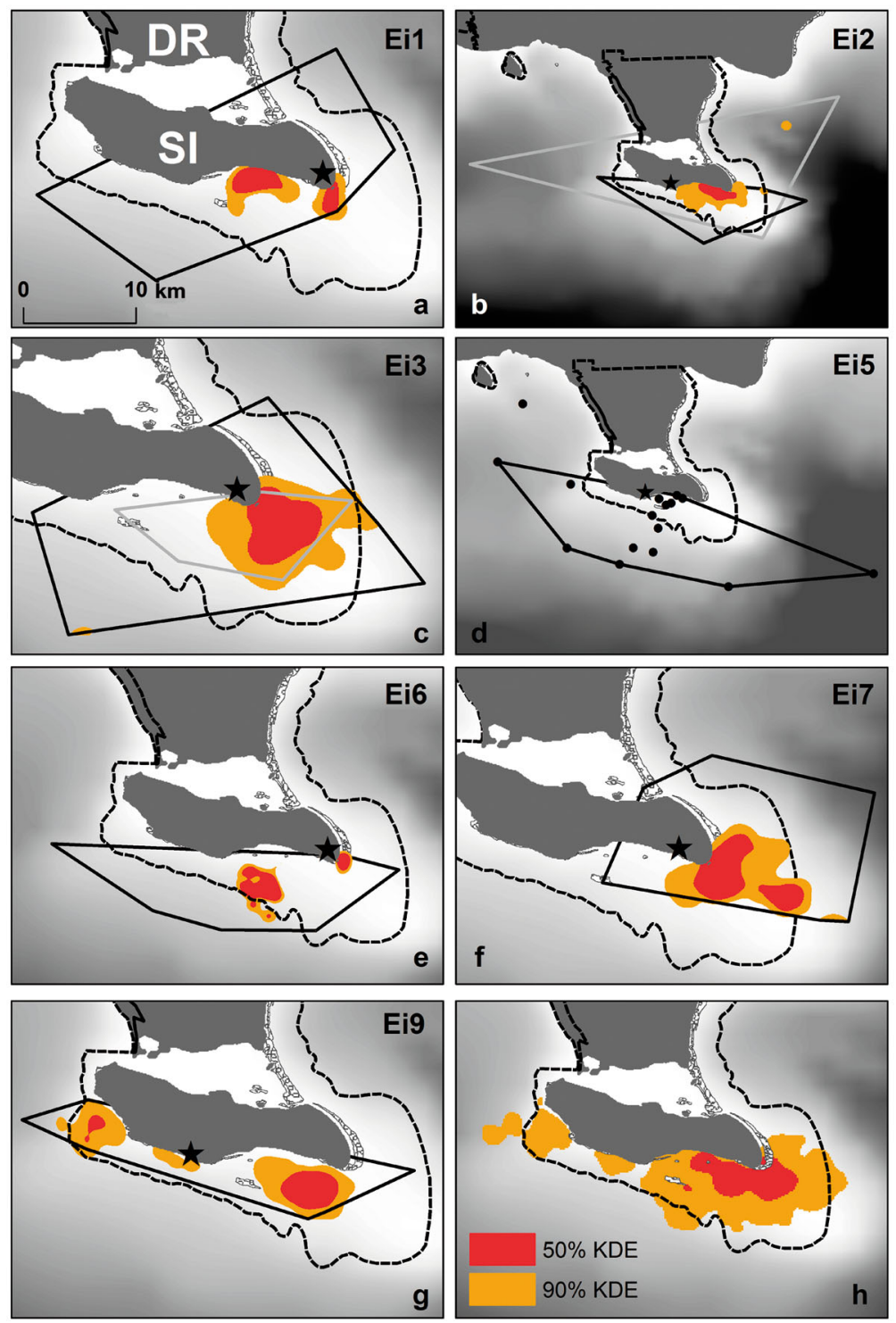

Fig. 2. Individual hawksbill turtle (Eretmochelys imbricata) internesting areas in Del Este National Park indicated by minimum convex polygons (MCP; solid lines) and 90\% (yellow) and 50\% (red) utilization distributions (UDs) for (a) Turtle Ei1, (b) Turtle Ei2, (c) Turtle Ei3, (d) Turtle Ei5, (e) Turtle Ei6, (f) Turtle Ei7, (g) Turtle Ei9 and (h) the common core-use area of these 7 turtles tracked during the nesting season identified using 50 and $90 \%$ UDs. For Turtles Ei2 and Ei3 two MCP areas, 1st nesting season (black polygon) and 2nd nesting season (light gray polygon), are shown. For these 2 turtles 50 and $90 \%$ KDEs include locations for the 2 nesting seasons recorded. DR: Dominican Republic. SI: Saona Island. Coral reef ecosystems are indicated by light gray outlines, and marine protected areas, by dashed black lines. Dark gray: land mass; white to black: bathymetry; stars: tagging locations
During the nesting season, all turtles remained in the territorial waters of the Dominican Republic, mostly over the continental shelf $(<200 \mathrm{~m}$ depth; Fig. 2). Turtles spent most of their time in areas characterized by relatively shallow waters, with KDE $50 \%$ for all turtles over water $<100 \mathrm{~m}$ deep $(64.4 \pm 22.8 \mathrm{~m})$. Turtles Ei2 and Ei5 made excursions beyond the shelf (e.g. to the $1000 \mathrm{~m}$ isobath; Fig. 2b,d). Turtles were usually located 1.4 to $4.3 \mathrm{~km}$ from the coast (SD range: $2.1-5.7 \mathrm{~km}$ ), and mean maximum distance from the coast was $22.4 \pm 9.2 \mathrm{~km}$ (range: 13-39 km; Table 1). Analyses of the turtles' daily locations showed that during the nesting season, of the 370 total tracking days, $306(82.7 \%)$ were within the borders of the DENP. The turtle's residency index (calculated for turtles with $>20$ d of data, i.e. excluding Turtle Ei5) ranged from 0.65 to $1.0(0.84 \pm 0.1)$, indicating a high degree of use of the protected area.

\section{Core-use internesting areas}

We calculated MCPs for 7 turtles, 2 of which (Turtles Ei2 and Ei3) transmitted data for a second nesting season, resulting in 9 MCPs (Table 2, Fig. 2). Internesting areas occupied by the turtles ranged from 68.4 to $1101.2 \mathrm{~km}^{2}(403.6 \pm 362.0$; Table 2). The $90 \%$ KDEs $(n=8)$ for the 6 turtles for which nesting season core areas were calculated were much smaller and ranged from 24.0 to $61.6 \mathrm{~km}^{2}(37.1 \pm$ $15.6 \mathrm{~km}^{2}$; Table 2), and the mean $50 \%$ KDEs area was $13.2 \pm 6.0 \mathrm{~km}^{2}$ (5.4 to $24.7 \mathrm{~km}^{2}$; Table 2). With the exception of Turtle Ei2, there was no substantive variation in home range size among the 7 hawksbill turtles tracked during their nesting season (Fig. 3), with large portions of MCPs and KDE overlapping (Fig. 2). Turtles Ei2 and Ei3 occupied similarly sized areas in the same locations during their 2 tracked nesting seasons (Fig. 2b,c). There were no correlations between turtle size and duration of the nesting season (Pearson's $t=-0.7$, $\mathrm{df}=5, \mathrm{p}=0.5$ ) or between turtle size and the nesting season area (Pearson's $t=$ -1.02 , df $=5, p=0.3)$. 


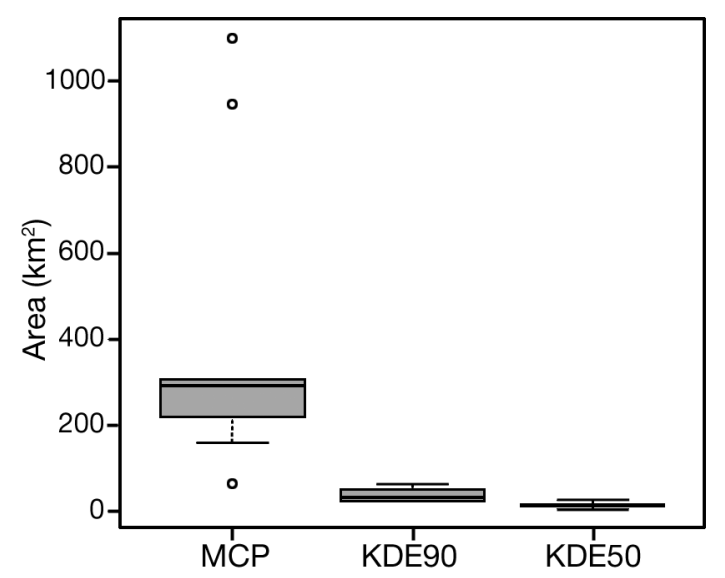

Fig. 3. Home range size of the 7 hawksbill turtles Eretmochelys imbricata tracked during their nesting season in the Dominican Republic, measured using Minimum Convex Polygons (MCP), Kernel Density Estimates of $90 \%$ of the core range (KDE90) and $50 \%$ of the core range (KDE50). Boxes show inter-quartile range, black horizontal line shows median values, whiskers show range. Outliers (for MCP) are shown as white circles and are for Turtle Ei2 (see 'Materials and methods' for descriptions)

\section{Common core-use areas}

The internesting common use area $90 \%$ and $50 \%$ KDEs were 212.2 and $37.9 \mathrm{~km}^{2}$, respectively (Fig. $2 \mathrm{~h}$ ). This common use area was situated on coral reefs at the easternmost tip of the island, and the individual home ranges for all 7 turtles overlapped, across turtles and years. Overall, the common core-use area during nesting was situated inside the DENP's boundaries (Fig. 2h). Generally speaking, the home ranges of turtles during their foraging periods (Fig. 4a) did not overlap with one another. However, 1 individual was tracked through 2 consecutive years and was tracked returning to the same foraging area (Fig. 4f).

\section{Foraging areas and MPAs}

Foraging areas of 5 females (Ei2, Ei3, Ei4, Ei8, Ei9) were located along the waters off Honduras and Nicaragua (Fig. 4a). In those waters there are 2 main protected areas, the Miskito Cays and the Seaflower MPA (part of the Seaflower Biosphere

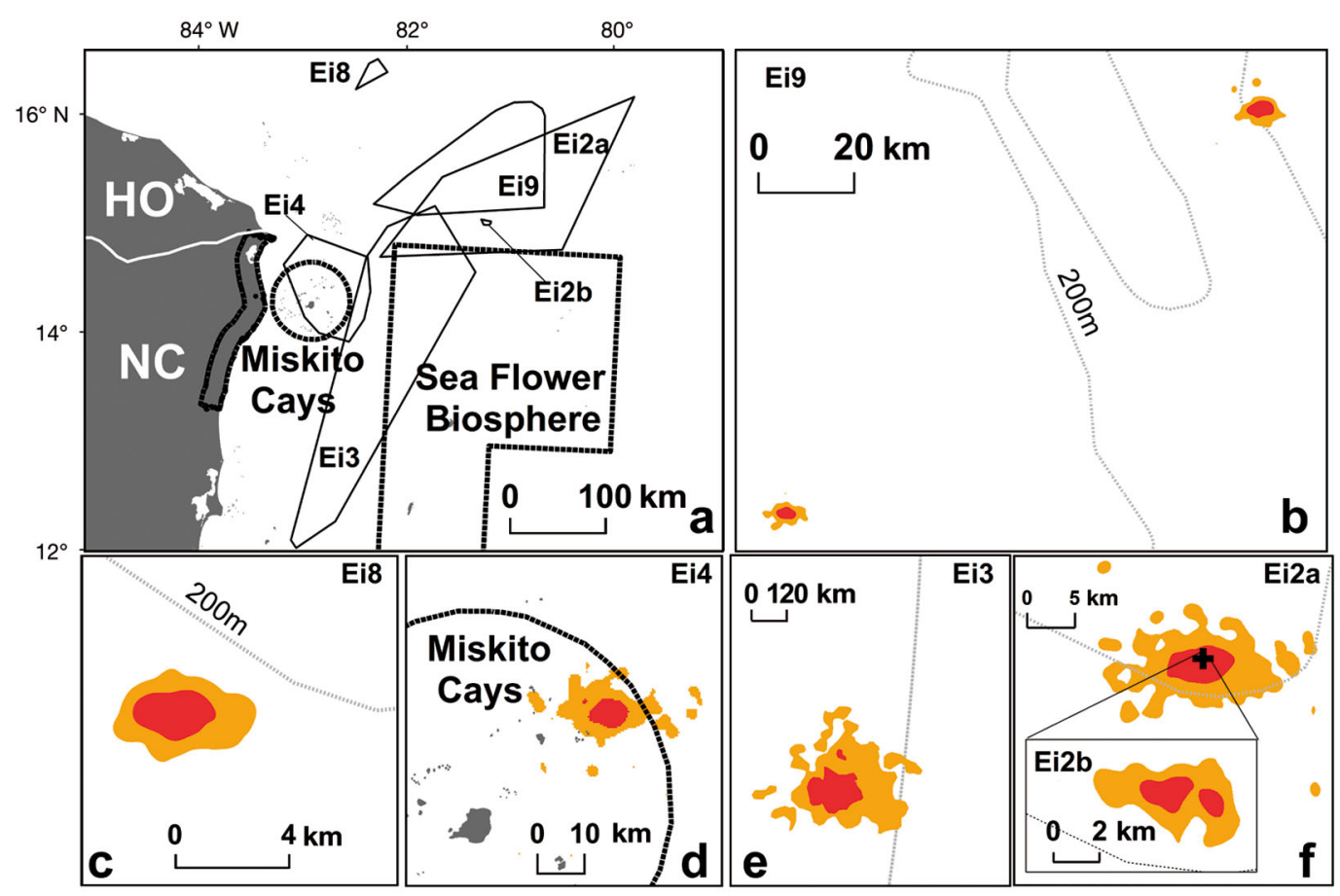

Fig. 4. (a) Minimum convex polygons (MCP; solid lines) of hawksbill turtles Eretmochelys imbricata at foraging areas off Nicaragua (NC) and Honduras (HO). The MCP of Turtle Ei2b shows the 2012 foraging period. The marine protected areas Miskito Cays and Seaflower (dashed black lines) are shown. Core-use areas defined by $90 \%$ (yellow) and $50 \%$ (red) utilisation distributions (UDs) for (b) Turtle Ei9 which occupied 2 separate areas during the same foraging period, (c) Turtle Ei8, (d) Turtle Ei4, (e) Turtle Ei3 and (f) Turtle Ei2: Ei2a shows the foraging period in 2008, the first year this turtle was observed; Ei2b (+, inset) shows the same turtle occupying the same area in 2012, the second year it was observed. Note different scales. Dashed 
Reserve, belonging to Colombia). The Miskito Cays $\left(27 \mathrm{~km}^{2}\right)$ is an archipelago located offshore along the north-eastern Caribbean coast of Nicaragua (Fig. 1). The seagrass beds and reefs in the cays are among the Atlantic's greatest foraging grounds for green (Chelonia mydas) and hawksbill marine turtles (Bjorndal \& Bolten 2003). The Seaflower MPA, located in the south-western Caribbean Sea (Fig. 1) is the largest MPA in the wider Caribbean $\left(65000 \mathrm{~km}^{2}\right)$, protecting mangroves, seagrass beds and the largest and most productive coral reefs in the region (Taylor et al. 2013).With the exception of Turtles Ei3 and Ei4, with residency indexes of 0.02 and 0.91, respectively (Seaflower Biosphere Reserve and Miskitos Cays, respectively), the turtles were not located in protected waters for any of their tracked foraging period (Fig. 4a-f). After nesting at Saona, Turtles Ei5 and Ei6 remained in DR waters within coastal reef ecosystems (Fig. 5a,b). Turtle Ei5 remained inside the JNP (residency index: 0.91; Fig. 5b). Turtle Ei6's foraging area was located in the waters adjacent to Bahía de las Calderas (southern DR coast) outside of MPAs (Fig. 5a). Turtle Ei7 travelled north-westward to the Bahamas, where its core-use area was not in protected waters (Fig. 5c).

\section{DISCUSSION}

The present study has highlighted space-use patterns for endangered hawksbill turtles in the DR, demonstrating some key novel findings for the population and providing support for key conservation recommendations.

\section{Internesting behaviour}

Nesting hawksbills from Saona Island remained in the waters adjacent to their nesting beaches, using small home range areas during internesting periods. Core activity areas occurred in shallow waters $(<200 \mathrm{~m})$ and were associated with coral reefs. Our results support previously described hawksbill internesting spatial behaviour observed in other internesting areas throughout the Caribbean (van Dam et al. 2008, Marcovaldi et al. 2012, Walcott et al. 2012). Although we did not record diving depth, it appears turtles were likely to have been making shallow dives; indeed, hawksbill turtles probably exhibit shallow diving behaviour throughout the year (Storch et al. 2005, Blumenthal et al. 2009). Regardless of the nesting location on the beach, core-use

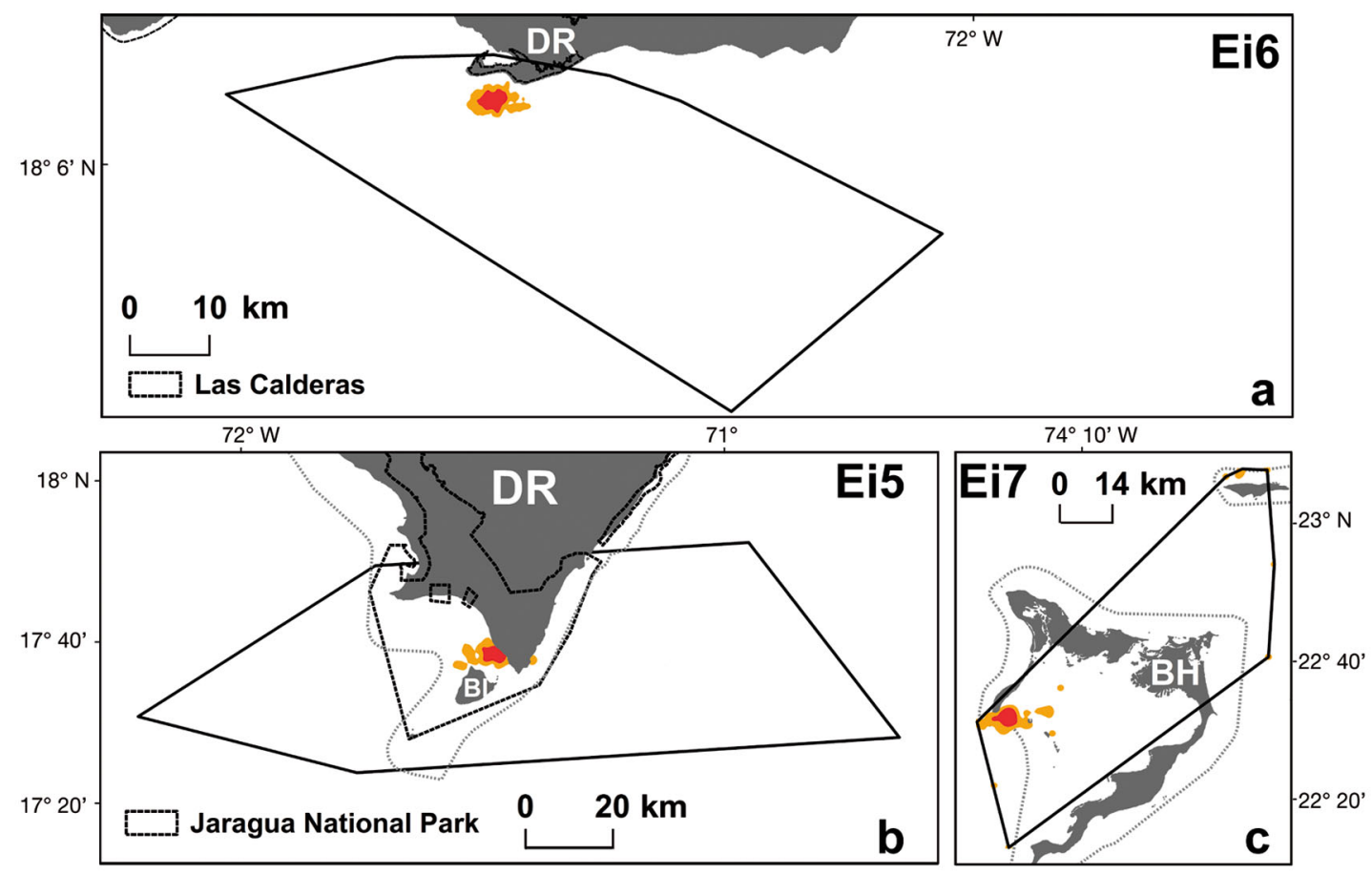

Fig. 5. Eretmochelys imbricata. Foraging core-use areas defined by minimum convex polygons and $90 \%$ (yellow) and $50 \%$ (red) utilisation distributions of (a) Turtle Ei6 near Las Calderas Natural Monument (south Dominican Republic); (b) Turtle Ei5 in waters inside Jaragua National Park boundaries (south-west DR; BI: Beata Island) and (c) Turtle Ei7 in waters of the Bahamas (BH). Note different scales. Dashed light grey line: $200 \mathrm{~m}$ bathymetric contour 
areas were situated on coral reefs at the eastern-most tip of the island. Turtle preference for particular internesting areas has been related to adequate resources and the quality of the habitat occupied (Hart et al. 2010). The abundance of fringing reef systems inside DENP's marine area likely accounts for hawksbill turtle affinity for this area. The abundance of sheltered resting sites (e.g. ledges and caves in coral reefs) could be an important resource, helping nesting females to preserve energy during their reproductive period (Houghton et al. 2008, Hart et al. 2010).

Nesting season activity patterns for Saona hawksbill turtles were similar to results for hawksbill turtles satellite tracked during the nesting season elsewhere. However, it should be noted that tagging date was the only confirmed nesting event; hence, nesting dates were inferred by turtle tracks (see 'Materials and methods' section), and nesting dates and internesting periods were approximated. Our estimated internesting period (mean: $15.5 \pm 0.9 \mathrm{~d}_{\text {; }}$ range: 14-17 d) was similar to ranges reported elsewhere (14-17 d; Barbados: Beggs et al. 2007; Mona Island: van Dam et al. 2008). Tracking-derived minimum clutch frequency ranged from 2 to 4 clutches, which is in accordance with conspecifics elsewhere (Witzell 1983). Saona turtles remained in the internesting area for only a few days following their final nesting event, supporting the hypothesis that hawksbill turtles may not forage during the nesting season, as has been proposed in other studies (e.g. van Dam et al. 2008).

\section{Core-use areas and MPAs}

Home range estimations provide knowledge of marine turtles' core areas of activity, underscoring hotspots for their protection (Scott et al. 2012, Schofield et al. 2013b, Pendoley et al. 2014). The results of the present study highlight that effective protection of reproductively active hawksbill turtles in the DR can most effectively take place within the waters of the DR itself. It should be noted that the number of tracked turtles studied in the present paper represents ca. $40 \%$ of the total annual nesting stock in the DR (Revuelta et al. 2012), so results may be representative of the entire population nesting in the DR.

Our results also reveal that, during their nesting season, hawksbill turtles from Saona Island remain mostly within the maritime limits of the DENP MPA. Although the DENP MPA in theory offers protection for this Critically Endangered species, in reality turtles face multiple anthropogenic threats inside the park.

Firstly, the expansion of tourism has increased the boat traffic around Saona Island, particularly in the west part, and has also increased the pressure on coral reefs from direct pollution (Wilkinson 2000). Secondly, artisanal fishermen have essentially uncontrolled access to the park, resulting in the depletion of large reef fish, conch and lobster populations (Chiappone et al. 2000). Finally, illegal capture of adult turtles by fisherman has also been documented (Revuelta et al. 2013).

Hawksbill turtles satellite tracked from Saona show a range of migratory strategies, with some turtles remaining near nesting sites in the DR waters and others migrating to international foraging grounds (Hawkes et al. 2012). This flexibility in migratory routes and foraging-area destinations has previously been reported for nesting populations of different species of marine turtles, e.g. green turtles in the Galapagos (Seminoff et al. 2008), loggerhead turtles in Greece (Hays et al. 2010) and flatback turtles in Australia (Pendoley et al. 2014). Most of the turtles that migrated internationally foraged in waters off Nicaragua and Honduras ( $\mathrm{n}=5$ ), which has already been confirmed as a preferred foraging ground for hawksbills nesting in other Caribbean areas, such as Costa Rica, the eastern Caribbean and Cuba (Troëng et al. 2005, Horrocks et al. 2011, Moncada et al. 2012), and also for other marine turtle species nesting in the Caribbean region (loggerhead: Masuda 2010; green turtle: Vander Zanden et al. 2013). While turtles were located within MPAs during the nesting season, at their foraging grounds they were mostly (78.0\% of total foraging days tracked) outside of any MPA. Of the 5 tracked turtles just one (Turtle Ei4) spent a large proportion of the time inside a protected area (Miskito Cays). However, the effectiveness of the protection in this area is questionable since legal and illegal marine turtle fisheries continue to exist (Bräutigam \& Eckert 2006). The lack of protection in the waters off Nicaragua and Honduras, thus, poses a potentially significant conservation problem, not only for many Caribbean hawksbill nesting populations, but also for other marine species. In the Bahamas, there are 8 marine national parks, and direct harvest of marine turtles is probably considerably less common. However, protected waters make up a small portion of the $630000 \mathrm{~km}^{2}$ exclusive economic zone of the Bahamas (<1\%), and, thus, it is not surprising that the turtle foraging here did so outside of protected areas. 
Turtle Ei5 stayed in DR waters, spending most of the time ( $91 \%$ of the total days tracked) within JNP maritime limits, which supports previous studies about the importance of this area for marine turtle conservation for the country, not only as a foraging ground for juveniles and adults, but also as a nesting area (León \& Diez 1999, Revuelta et al. 2012). The second potential foraging ground in the DR was located in waters adjacent to the Natural Monument Bahía de Calderas along the south coast of the country. This protected area encompasses around $15 \mathrm{~km}$ of sand dunes, but does not yet incorporate the sea. Sporadic nesting by Chelonia mydas has also been detected on these beaches (Y. M. León pers. obs.). Despite the evident importance of this area for biodiversity conservation, and its protected status, it is threatened by the extraction of sand for commercial purposes and illegal construction by the hotel industry, as well as indiscriminate fishing activities (Perdomo et al. 2010). Such lack of enforcement of conservation actions in protected areas hinders the effective protection of these critical habitats for marine turtles and is an urgent target for improved conservation.

\section{Conclusions and conservation recommendations}

In this study, we described DR hawksbill nesting turtles' use of MPAs at nesting and feeding grounds, adding information to the use of MPAs by this species in the Caribbean region. This information highlights the significance of protected areas in the DR for internesting and foraging hawksbills, showing the need to enforce existing legislation of the protected areas in the country. Hawksbill turtles use waters inside the protected areas of DENP and JNP yearround, areas that are severely threatened by human activities. Hence, efforts must be increased to mitigate illegal fishing in the waters of these parks. In the case of waters around Saona, we recommend the creation of a near-shore zone of maximum protection that would enhance the protection of the rookery in this heavily used area (i.e. by restricting the boat traffic in this zone). Likewise, we propose the expansion of Las Calderas Natural Monument boundaries offshore, due to its importance, not only for turtles, but also for other species and ecosystems. The present study also supports that the waters off Nicaragua and Honduras are exceptionally important foraging areas for hawksbills in the Caribbean. These grounds overlap with those identified for other endangered species, strengthening the importance of protecting them. We highly recommend that the MPAs set up for marine turtle conservation in this region are reassessed. In line with the recommendations made by Edgar et al. (2014), implementation of no-fishing zones, an increase in the level of compliance and the extension of boundaries would enhance the effectivity of MPAs and help secure marine biodiversity.

Acknowledgements. Funding for the transmitters came from the JM Kaplan Foundation award to the World Wildlife Fund, Canada, and from several European institutions: the Spanish International Cooperation Agency (AECI Projects A/2991/05 and A/5641/06), the Spanish Ministry of Education and Sciences (CGL2006-02936-BOS and CGL201130413) and the General Foundation of the University of Valencia. The project also received funding from the European Union (Marie Curie Grants FP6 and FP7). L.H. was supported by the WWF MacArthur project 'Developing an approach to adaptation to climate change in the marine turtles: the hawksbill turtle as an indicator species' (awarded to C. Drews). Work was carried out under permit in the DR. L.H. was supported by a Biotechnology and Biological Sciences Research Council (BBSRC) post-doctoral fellowship. J.T. and J.A.R. were supported by Project Prometeo/2011/40 of Conselleria de Educacio (Generalitat Valenciana) and Project CGL2011-30413 of the Spanish Ministry of Economy and Competitiveness. B.J.G. was supported by the Darwin Initiative, Natural Environment Research Council (NERC) and the Peninsula Research Institute for Marine Renewable Energy (PRIMaRE). Special thanks are due to the 3 anonymous reviewers for suggestions that substantially improved a previous version of the manuscript.

\section{LITERATURE CITED}

Agardy TM (1994) Advances in marine conservation: the role of marine protected areas. Trends Ecol Evol 9: $267-270$

Allen ZC, Shah NJ, Grant A, Derand GD, Bell D (2010) Hawksbill turtle monitoring in Cousin Island Special Reserve, Seychelles: an eight-fold increase in annual nesting numbers. Endang Species Res 11:195-200

> Beggs JA, Horrocks JA, Krueger BH (2007) Increase in hawksbill sea turtle Eretmochelys imbricata nesting in Barbados, West Indies. Endang Species Res 3:159-168

Bjorndal KA, Bolten AB (2003) From ghosts to key species: restoring sea turtle populations to fulfill their ecological roles. Mar Turtle Newsl 100:16-21

Bjorndal KA, Jackson JBC (2003) Role of sea turtles in marine ecosystems: reconstructing the past. In: Lutz PL, Musick JA, Wyneken J (eds) Biology of sea turtles, Volume II. CRC Press, Boca Raton, FL, p 259-273

Blumenthal JM, Solomon JL, Bell CD, Austin TJ and others (2006) Satellite tracking highlights the need for international cooperation in marine turtle management. Endang Species Res 2:51-61

Blumenthal JM, Austin TJ, Bothwell JB, Broderick AC and others (2009) Diving behavior and movements of juvenile hawksbill turtles Eretmochelys imbricata on a Caribbean coral reef. Coral Reefs 28:55-65 
Bograd SJ, Block BA, Costa DP, Godley BJ (2010) Biologging technologies: new tools for conservation. Introduction. Endang Species Res 10:1-7

Bräutigam A, Eckert KL (2006) Turning the tide: exploitation, trade and management of marine turtles in the Lesser Antilles, Central America, Colombia and Venezuela. TRAFFIC International, Cambridge

Burt WH (1943) Territoriality and home range concepts as applied to mammals. J Mammal 24:346-352

> Chiappone M, Sluka R, Sullivan Sealey K (2000) Groupers (Pisces: Serranidae) in fished and protected areas of the Florida Keys, Bahamas and northern Caribbean. Mar Ecol Prog Ser 198:261-272

CLS (2011) Argos user's manual: worldwide tracking and environmental monitoring by satellite. Available at: http: //www.argos-system.org/web/en/76-user-s-manual.php (accessed 20 November 2013)

> Coyne MS, Godley BJ (2005) Satellite Tracking and Analysis Tool (STAT): an integrated system for archiving, analyzing and mapping animal tracking data. Mar Ecol Prog Ser 301:1-7

> Cuevas E, Abreu-Grobois FA, Guzman-Hernandez V, Liceaga-Correa MA, van Dam RP (2008) Post-nesting migratory movements of hawksbill turtles Eretmochelys imbricata in waters adjacent to the Yucatan Peninsula, Mexico. Endang Species Res 10:123-133

Edgar GJ (2011) Does the global network of marine protected areas provide an adequate safety net for marine biodiversity? Aquat Conserv 21:313-316

Edgar GJ, Stuart-Smith RD, Willis TJ, Kininmonth S and others (eds) (2014) Global conservation outcomes depend on marine protected areas with five key features. Nature 506:216-220

ESRI (Environmental Systems Research Institute) (2010) ArcGIS 10.0 GIS. ESRI, Redlands, CA

> Gaos AR, Lewison RL, Wallace BP, Yañez IL and others (2012) Spatial ecology of critically endangered hawksbill turtles Eretmochelys imbricata: implications for management and conservation. Mar Ecol Prog Ser 450: 181-194

> Godley BJ, Blumenthal JM, Broderick AC, Coyne MS, Godfrey MH, Hawkes LA, Witt MJ (2008) Satellite tracking of sea turtles: Where have we been and where do we go next? Endang Species Res 4:3-22

> Hart KM, Zawada DG, Fujisaki I, Lidz BH (2010) Internesting habitat-use patterns of loggerhead sea turtles: enhancing satellite tracking with benthic mapping. Aquat Biol 11:77-90

Hart KM, Lamont MM, Sartain AR, Fujisaki I, Stephens BS (2013) Movements and habitat-use of loggerhead sea turtles in the northern Gulf of Mexico during the reproductive period. PLoS ONE 8:e66921

> Hawkes LA, Witt MJ, Broderick AC, Coker JW and others (2011) Home on the range: spatial ecology of loggerhead turtles in Atlantic waters of the USA. Divers Distrib 17: 624-640

Hawkes LA, Tomás J, Revuelta O, León YM and others (2012) Migratory patterns in hawksbill turtles described by satellite tracking. Mar Ecol Prog Ser 461:223-232

> Hays GC, Luschi P, Papi F, del Seppia C, Marsh R (1999) Changes in behaviour during the inter-nesting period and post-nesting migration for Ascension Island green turtles. Mar Ecol Prog Ser 189:263-273

- Hays GC, Akesson S, Godley BJ, Luschi P, Santidrian P (2001) The implications of location accuracy for the inter- pretation of satellite-tracking data. Anim Behav 61: 1035-1040

> Hays GC, Fossette S, Katselidis KA, Schofield G, Gravenor MB (2010) Breeding periodicity for male sea turtles, operational sex ratios, and implications in the face of climate change. Conserv Biol 24:1636-1643

> Hoffmann M, Belant JL, Chanson JS, Cox NA and others (2011) The changing fates of the world's mammals. Philos Trans R Soc Lond B 366:2598-2610

Hooge PN, Eichenlaub WM, Solomon EK (1999) The animal movement program. USGS, Alaska Biological Science Center. Available at: www.absc.usgs.gov/glba/gistools (accessed 13 Oct 2013)

Hooker SK, Biuw M, McConnell BJ, Miller PJ, Sparling CE (2007) Biologging science: logging and relaying physical and biological data using animal-attached tags. DeepSea Res II 54:177-182

> Horrocks JA, Krueger BH, Fastigi M, Pemberton EL, Eckert KL (2011) International movements of adult female hawksbill turtles (Eretmochelys imbricata): first results from the Caribbean's marine turtle tagging centre. Chelonian Conserv Biol 10:18-25

> Houghton JDR, Cedras A, Myers AE, Liebsch N, Metcalfe JD, Mortimer JA, Hays GC (2008) Measuring the state of consciousness in a free-living diving sea turtle. J Exp Mar Biol Ecol 356:115-120

IUCN (International Union for Conservation of Nature) (2013) The IUCN Red List of Threatened Species. Available at: www.iucnredlist.org. (accessed 11 Nov 2013)

James MC, Ottensmeyer CA, Myers RA (2005) Identification of high-use habitat and threats to leatherback sea turtles in northern waters: new directions for conservation. Ecol Lett 8:195-201

Laver PN, Kelly MJ (2008) A critical review of home range studies. J Wildl Manag 72:290-298

León YM, Bjorndal KA (2002) Selective feeding in the hawksbill turtle, an important predator in coral reef ecosystems. Mar Ecol Prog Ser 245:249-258

León YM, Diez CE (1999) Population structure of hawksbill turtles on a foraging ground in the Dominican Republic. Chelonian Conserv Biol 3:230-236

Luschi P, Hays GC, Del Seppia C, Marsh R, Papi F (1998) The navigational feats of green sea turtles migrating from Ascension Island investigated by satellite telemetry. Proc R Soc B 265:2279-2284

Macleod DVL (2001) Parks or people? National parks and the case of Del Este, Dominican Republic. Prog Dev Stud $1: 221-235$

Marcovaldi MÂ, Lopez GG, Soares LS, López-Mendilaharsu M (2012) Satellite tracking of hawksbill turtles Eretmochelys imbricata nesting in northern Bahia, Brazil: turtle movements and foraging destinations. Endang Species Res 17:123-132

Mason TJ, Lowe CG (2010) Home range, habitat use, and site fidelity of barred sand bass within a southern California marine protected area. Fish Res 106:93-101

Masuda A (2010) Natal origin of juvenile loggerhead turtles from foraging ground in Nicaragua and Panama estimated using mitochondria DNA. MSc dissertation, California State University, Chico, CA

> Maxwell SM, Breed GA, Nickel BA, Makanga-Bahouna J and others (2011) Using satellite tracking to optimize protection of long-lived marine species: olive ridley sea turtle conservation in Central Africa. PLoS ONE 6: e19905 
Mazaris AD, Almpanidou V, Wallace BP, Pantis JD, Schofield G (2014) A global gap analysis of sea turtle protection coverage. Biol Conserv 173:17-23

Meylan A (1988) Spongivory in hawksbill turtles: a diet of glass. Science 239:393-395

Meylan PA, Meylan AB, Gray JA (2011) The ecology and migrations of sea turtles. 8. Tests of the developmental habitat hypothesis. Bull Am Mus Nat Hist 357:1-70

Miller JD (1997) Reproduction in sea turtles. In: Lutz PL, Musick JA (eds) The biology of sea turtles. CRC Press, Boca Raton, FL, p 51-81

Moncada FG, Hawkes LA, Fish MR, Godley BJ and others (2012) Patterns of dispersal of hawksbill turtles from the Cuban shelf inform scale of conservation and management. Biol Conserv 148:191-199

Pendoley KL, Schofield G, Whittock PA, Ierodiaconou D, Hays GC (2014) Protected species use of a coastal marine turtle migratory corridor connecting Australian MPAs. Mar Biol 161:1455-1466

Perdomo L, Arias Y, León YM, Wege D (2010) Áreas importantes para la conservación de las aves en la República Dominicana. Grupo Jaragua y el programa IBA-Caribe de BirdLife International, Santo Domingo

Phillips KP, Jorgensen TH, Jolliffe KG, Jolliffe SM, Henwood J, Richardson DS (2013) Reconstructing paternal genotypes to infer patterns of sperm storage and sexual selection in the hawksbill turtle. Mol Ecol 22:2301-2312

Powell RA (2000) Animal home ranges and territories and home range estimators. In: Boitani $\mathrm{L}$, Fuller $\mathrm{T}$ (eds) Research techniques in animal ecology: controversies and consequences. Columbia University Press, New York, NY, p 65-110

$>$ Read AJ, Drinker P, Northridge S (2006) Bycatch of marine mammals in U.S. and global fisheries. Conserv Biol 20: 163-169

> Rees AF, Al Saady S, Broderick AC, Coyne MS, Papathanasopoulou N, Godley BJ (2010) Behavioural polymorphism in one of the world's largest populations of loggerhead sea turtles Caretta caretta. Mar Ecol Prog Ser 418: 201-212

> Revuelta O, León YM, Feliz P, Godley BJ, Raga JA, Tomás J (2012) Protected areas host important remnants of marine turtle nesting stocks in the Dominican Republic. Oryx 46:348-358

Revuelta O, León YM, Aznar FJ, Raga JA, Tomás J (2013) Running against time: conservation of the remaining hawksbill turtle (Eretmochelys imbricata) nesting population in the Dominican Republic. J Mar Biol Assoc UK 93:1133-1140

Rutz C, Hays GC (2009) New frontiers in biologging science. Biol Lett 5:289-292

Schofield G, Hobson VJ, Lilley MKS, Katselidis KA, Bishop CM, Brown P, Hays GC (2010) Inter-annual variability in the home range of breeding turtles: implications for current and future conservation management. Biol Conserv 143:722-730

Schofield G, Dimadi A, Fossette S, Katselidis KA and others (2013a) Satellite tracking large numbers of individuals to

Editorial responsibility: Matthew Godfrey, Beaufort, North Carolina, USA infer population level dispersal and core areas for the protection of an endangered species. Divers Distrib 19: 834-844

Schofield G, Scott R, Dimadi A, Fossette S and others (2013b) Evidence-based marine protected area planning for a highly mobile endangered marine vertebrate. Biol Conserv 161:101-109

- Scott R, Hodgson DJ, Witt MJ, Coyne MS and others (2012) Global analysis of satellite tracking data shows that adult green turtles are significantly aggregated in Marine Protected Areas. Glob Ecol Biogeogr 21:1053-1061

Seminoff JA, Zárate P, Coyne M, Foley DG, Parker D, Lyon BN, Dutton PH (2008) Post-nesting migrations of Galápagos green turtles, Chelonia mydas, in relation to oceanographic conditions: integrating satellite telemetry with remotely sensed ocean data. Endang Species Res 4: $57-72$

> Shaffer SA, Tremblay Y, Weimerskirch H, Scott D and others (2006) Migratory shearwaters integrate oceanic resources across the Pacific Ocean in an endless summer. Proc Natl Acad Sci USA 103:12799-12802

> Shillinger GL, Palacios DM, Bailey H, Bograd SJ and others (2008) Persistent leatherback turtle migrations present opportunities for conservation. PLoS Biol 6:e171

Storch S, Wilson RP, Hillis-Starr ZM, Adelung D (2005) Cold-blooded divers: temperature-dependent dive performance in wild hawksbill turtles Eretmochelys imbricata. Mar Ecol Prog Ser 293:263-271

Taylor E, Baine M, Killmer A, Howard M (2013) Seaflower marine protected area: governance for sustainable development. Mar Policy 41:57-64

> Troëng S, Dutton PH, Evans D (2005) Migration of hawksbill turtles Eretmochelys imbricata from Tortuguero, Costa Rica. Ecography 28:394-402

> Tucker AD (2010) Nest site fidelity and clutch frequency of loggerhead turtles are better elucidated by satellite telemetry than by nocturnal tagging efforts: implications for stock estimation. J Exp Mar Biol Ecol 383:48-55

van Dam RP, Diez CE, Balazs GH, Colón Colón LA, McMillan WO, Schroeder B (2008) Sex-specific migration patterns of hawksbill turtles breeding at Mona Island. Endang Species Res 4:85-94

- Vander Zanden HB, Arthur KE, Bolten AB, Popp BN and others (2013) Trophic ecology of a green turtle breeding population. Mar Ecol Prog Ser 476:237-249

Walcott J, Eckert S, Horrocks JA (2012) Tracking hawksbill sea turtles (Eretmochelys imbricata) during inter-nesting intervals around Barbados. Mar Biol 159:927-938

Wielgus J, Cooper E, Torres R, Burke L (2010) Coastal capital: Dominican Republic. Case studies on the economic value of coastal ecosystems in the Dominican Republic. Working paper. World Resources Institute, Washington, DC

Wilkinson CR (2000) Status of coral reefs of the world: 2000. Australian Institute of Marine Science, Townsville

Witzell WN (1983) Synopsis of biological data on the hawksbill turtle Eretmochelys imbricata (Linnaeus, 1766). FAO Fish Synop 137:1-78

Submitted: March 14, 2014; Accepted: November 18, 2014 Proofs received from author(s): March 19, 2015 